\title{
A Qualitative Inquiry and Review of Telemedicine: A Case Study of Cameroon
}

\author{
Felicitas Yari ${ }^{1}$, Foluso Ayeni ${ }^{2}$, , Sylvester Yari ${ }^{3}$, Victor Mbarika ${ }^{4}$ and Godswill Katchoua ${ }^{5}$ \\ ${ }^{1}$ Department of Public Policy, Global Technology Management and Policy Research Group, USA \\ ${ }^{2}$ Global Technology Management and Policy Research Group, USA \\ ${ }^{3}$ Oschner LSU Shreveport/Monroe family medicine residency program, USA
}

${ }^{4}$ Global Technology Management and Policy Research Group, USA

${ }^{5}$ George Mason University, Fairfax-Virginia, USA

*Corresponding author: Foluso Ayeni, Global Technology Management and Policy Research Group, USA

\section{ARTICLE INFO}

Received: 幽 October 15, 2019

Published:

Citation: Felicitas Yari, Foluso Ayeni, Sylvester Yari, Victor Mbarika, Godswill Katchoua. A Qualitative Inquiry and Review of Telemedicine: A Case Study of Cameroon. Biomed J Sci \& Tech Res 22(2)2019. BJSTR. MS.ID.003725.

Keywords: Telemedicine; ICT; Knowledge; Review

\begin{abstract}
Cameroon is classified by the World Health Organization (WHO) as having a critical shortage of health personnel despite healthcare being one of the nation's Millennium Development Goals. Telemedicine has the potential of addressing the issue of shortage of health personnel in Cameroon and improving on the health conditions of rural patients. The concept of Telemedicine refers to the use of information and telecommunication technologies to develop information and expertise necessary for healthcare services provision. It also involves collaboration in order to develop geographically separated participants, including physicians and patients. Cameroon has been slow in implementing and sustaining this concept unlike other African countries such as Ghana, Mali, South Africa, Uganda. People in the rural areas are still moving to urban spaces in search of better health facilities instead of staying where they are and using new technologies to reach the specialists both nationally and internationally. Hence, in this paper we present an extensive literature review that produced peer-reviewed interventions of telemedicine in sub-Saharan Africa. This study was performed to assess the level of knowledge and perception of the target population towards Telemedicine in Cameroon.
\end{abstract}

\section{Introduction}

Cameroon, a country located in the Central Africa that shares borders with Nigeria and Chad. With a population of roughly 24 million people, Cameroon has seen a rise in poor healthcare and premature deaths due to A good start to running a telemedicine program is conjoining a rural kiosk through which medical information can be sent to a doctor who is in an urban area. However, history shows that people used to visit the kiosk when it first started, but numbers began to decline. Even though there were challenges with the kiosk project in the beginning, it later became a functional project in the end [1]. Currently the status of telemedicine in Cameroon is dwindling. A South African tech expert, John Akintosin stated that there has been impressive broadband access that is even good in rural areas [1]. Despite this, Telemedicine has become more difficult to deploy to rural areas.
While some countries have corporations that help with providing telemedicine, Cameroon has continued to suffer a major setback. In this paper we will cover the present status of telemedicine in Sub-Saharan Africa and how it has either improved or remained constant since the first project back in 2000. Different studies will also be discussed as far as how they have worked and if there were any pros or cons to the methods being used. Lastly, we will discuss the possible future of telemedicine in Cameroon with either improving current methods or starting new ones.

\section{Literature Review}

The search for interventions of telemedicine in sub-Saharan Africa was restricted to English language and was carried out by a wide search on Google-Scholar. This wide search includes peer- 
reviewed journals, conference proceedings, books and archives from World Health Organization. To retrieve best results, the following databases and literature resources, PUB MED and Southern University Online. Library. In all, we identified around
110 sources, which were reduced to 20 . This reduction was based on our inclusion criteria which are our keywords. The result of database search, that is, the peer-reviewed definitions are listed below (Table 1).

Table 1: Literature Study Summaries.

\begin{tabular}{|c|c|c|c|c|c|c|c|}
\hline $\mathbf{S} / \mathbf{N}$ & Author/Year & Title & $\begin{array}{l}\text { Type of } \\
\text { study }\end{array}$ & Sample & $\begin{array}{l}\text { Data Collection } \\
\text { Approach }\end{array}$ & Limitations & Key Findings \\
\hline 1 & $\begin{array}{l}\text { Edoh T et al. } \\
\text { (2016) }\end{array}$ & $\begin{array}{c}\text { Predicting } \\
\text { Telemedicine system } \\
\text { user satisfaction in Sub } \\
\text { Saharan Africa }\end{array}$ & $\begin{array}{l}\text { Mixed } \\
\text { Method }\end{array}$ & $\begin{array}{l}20 \text { patients and } \\
5 \text { healthcare } \\
\text { practitioners }\end{array}$ & $\begin{array}{l}\text { Survey and } \\
\text { interviews }\end{array}$ & $\begin{array}{l}\text { The study did not investigate } \\
\text { how the prediction of } \\
\text { user satisfaction levels } \\
\text { could influence system } \\
\text { implementation and the use } \\
\text { or launch of tele-healthcare } \\
\text { solutions for improving } \\
\text { healthcare provision in } \\
\text { medically underserved } \\
\text { regions }\end{array}$ & $\begin{array}{c}\text { The outcomes in } \\
\text { our study may help } \\
\text { eHealth application and } \\
\text { telemedicine developers } \\
\text { to predict user satisfaction } \\
\text { with an application } \\
\text { without conducting a } \\
\text { costly survey to evaluate } \\
\text { QoE and subsequently fix } \\
\text { any issues to increase QoS } \\
\text { and thus QoE. }\end{array}$ \\
\hline 2 & $\begin{array}{l}\text { Mars M } \\
(2013)\end{array}$ & $\begin{array}{l}\text { Telemedicine and } \\
\text { advances in urban } \\
\text { and rural health care } \\
\text { delivery in Africa }\end{array}$ & $\begin{array}{l}\text { Qualitative } \\
\text { research }\end{array}$ & $\begin{array}{l}\text { Case study } \\
\text { reviews }\end{array}$ & $\begin{array}{l}\text { Systematic } \\
\text { literature review }\end{array}$ & $\begin{array}{l}\text { Legal and ethical issues in } \\
\text { Telemedicine have not been } \\
\text { resolved in Africa and there } \\
\text { are still a lot of obstacles in } \\
\text { Telemedicine adoption. }\end{array}$ & $\begin{array}{l}\text { Tele education is lacking } \\
\text { in Africa and mobile } \\
\text { phones have the potential } \\
\text { to skyrocket the use of } \\
\text { Telemedicine in Africa }\end{array}$ \\
\hline 3 & $\begin{array}{l}\text { Ekanoye F et } \\
\text { al. (2017) }\end{array}$ & $\begin{array}{c}\text { Telemedicine diffusion } \\
\text { in a developing } \\
\text { country: A case of } \\
\text { Nigeria }\end{array}$ & $\begin{array}{l}\text { Qualitative } \\
\text { research }\end{array}$ & Case Study & $\begin{array}{c}\text { Systematic } \\
\text { literature review }\end{array}$ & $\begin{array}{c}\text { Lack of proper Telemedicine } \\
\text { structure in Nigeria }\end{array}$ & $\begin{array}{l}\text { In order for Telemedicine } \\
\text { to function properly in SSA } \\
\text { there must be improved } \\
\text { infrastructure vision } \\
\text { finance training programs } \\
\text { and enough doctors on call } \\
\text { to name a few. }\end{array}$ \\
\hline 4 & $\begin{array}{l}\text { Shiferaw F } \\
\text { \& Zolfo M } \\
\text { (2012) }\end{array}$ & $\begin{array}{l}\text { The role of Information } \\
\text { and Communication } \\
\text { Technology towards } \\
\text { universal health } \\
\text { coverage: the first } \\
\text { steps of a Telemedicine } \\
\text { project in Ethiopia }\end{array}$ & $\begin{array}{l}\text { Mixed } \\
\text { Method }\end{array}$ & $\begin{array}{l}10 \text { sites for } \\
\text { pilot study and } \\
20 \text { physicians } \\
\text { trained. }\end{array}$ & $\begin{array}{l}\text { Descriptive Case } \\
\text { study }\end{array}$ & $\begin{array}{l}\text { The pilot study failed } \\
\text { due to the fact that it } \\
\text { was implemented by few } \\
\text { practitioners in few places } \\
\text { and the results cannot be } \\
\text { generalized }\end{array}$ & $\begin{array}{l}\text { The study proved that ICT } \\
\text { application could reduce } \\
\text { shortage of healthcare } \\
\text { personnel in Ethiopia } \\
\text { and that other factors } \\
\text { such as e-governance } \\
\text { should be considered for } \\
\text { Telemedicine to succeed in } \\
\text { Ethiopia. }\end{array}$ \\
\hline 5 & $\begin{array}{l}\text { Bediang G et } \\
\text { al.(2014) }\end{array}$ & $\begin{array}{c}\text { The RAFT } \\
\text { Telemedicine network: } \\
\text { lessons learnt and } \\
\text { perspectives from a } \\
\text { decade of educational } \\
\text { and clinical services } \\
\text { in low- and middle } \\
\text {-income countries. }\end{array}$ & $\begin{array}{l}\text { Qualitative } \\
\text { research }\end{array}$ & $\begin{array}{l}\text { Scientific } \\
\text { papers reports } \\
\text { workshop } \\
\text { proceedings } \\
\text { informal } \\
\text { discussions }\end{array}$ & Literature review & $\begin{array}{l}\text { The RAFT project lacked } \\
\text { good methodologies for } \\
\text { impact evaluation }\end{array}$ & $\begin{array}{l}\text { The RAFT project has } \\
\text { offered lots of educational } \\
\text { health care and clinical } \\
\text { programs including its } \\
\text { expansion to Nepal and } \\
\text { Bolivia. }\end{array}$ \\
\hline 6 & $\begin{array}{l}\text { Mars M } \\
(2010)\end{array}$ & $\begin{array}{c}\text { Health capacity } \\
\text { Development through } \\
\text { Telemedicine in Africa }\end{array}$ & $\begin{array}{l}\text { Qualitative } \\
\text { study }\end{array}$ & $\begin{array}{l}\text { Review of } \\
\text { literature } \\
\text { reports } \\
\text { personal } \\
\text { observation }\end{array}$ & Literature review & $\begin{array}{l}\text { SSA has a shortage of health } \\
\text { workers and Telemedicine } \\
\text { and Tele-education will } \\
\text { help address shortage } \\
\text { of healthcare and lack of } \\
\text { knowledge problems }\end{array}$ & $\begin{array}{l}\text { Tele-education is more } \\
\text { successful in terms of } \\
\text { implementation than } \\
\text { Telemedicine }\end{array}$ \\
\hline 7 & $\begin{array}{l}\text { Jivraj I et al. } \\
\text { (2011) }\end{array}$ & $\begin{array}{l}\text { Prevalence and } \\
\text { severity of Diabetes } \\
\text { Retinopathy in North } \\
\text { West Cameroon } \\
\text { as identified by } \\
\text { Ophthalmology }\end{array}$ & $\begin{array}{l}\text { Qualitative } \\
\text { study }\end{array}$ & $\begin{array}{l}253 \text { patients` } \\
\text { eyes were } \\
\text { examined }\end{array}$ & $\begin{array}{l}\text { Retrospective } \\
\text { review }\end{array}$ & $\begin{array}{c}\text { Diagnosing and managing } \\
\text { the prevalence of diabetes } \\
\text { which is fast increasing in } \\
\text { Africa }\end{array}$ & $\begin{array}{l}\text { Out of the } 253 \text { patients } \\
\text { eyes that were reviewed } \\
\text { Diabetic retinopathy } \\
\text { was found to be } \\
\text { common in people with } \\
\text { diabetes who attended } \\
\text { teleophthalmology clinics } \\
\text { in Northwest Cameroon. }\end{array}$ \\
\hline
\end{tabular}




\begin{tabular}{|c|c|c|c|c|c|c|c|}
\hline 8 & $\begin{array}{l}\text { Sarfo FS et al. } \\
\quad \text { (2017) }\end{array}$ & $\begin{array}{l}\text { Tele-neurology in Sub } \\
\text { Saharan Africa : A } \\
\text { systematic review of } \\
\text { literature }\end{array}$ & $\begin{array}{l}\text { Qualitative } \\
\text { study }\end{array}$ & $\begin{array}{l}\text { Articles from } \\
\text { PubMed and } \\
\text { Cochrane } \\
\text { library from } \\
\text { January } 11980 \\
\text { to April } 302017 \\
\text { were reviewed }\end{array}$ & Literature review & $\begin{array}{l}\text { Shortage of neurologists } \\
\text { networks to utilize tele } \\
\text { neurology platforms in order } \\
\text { to improve on neurology } \\
\text { care in SSA. }\end{array}$ & $\begin{array}{l}\text { It was observed that } \\
\text { feasibility and satisfaction } \\
\text { of participants with } \\
\text { telemedicine as well as } \\
\text { improved knowledge base } \\
\text { of participants after the } \\
\text { educational course but } \\
\text { noted access to healthcare } \\
\text { by patients did not ch No } \\
\text { studies have evaluated } \\
\text { the use of telemedicine } \\
\text { for care of patients with } \\
\text { neurological disorders }\end{array}$ \\
\hline 9 & $\begin{array}{l}\text { Blaya JA et al. } \\
\quad(2010)\end{array}$ & $\begin{array}{l}\text { E-Health technologies } \\
\text { show promise in } \\
\text { developing countries }\end{array}$ & $\begin{array}{l}\text { Mixed } \\
\text { Methods }\end{array}$ & $\begin{array}{l}2043 \text { citations } \\
\text { searched }\end{array}$ & $\begin{array}{l}\text { Survey interviews } \\
\text { focus groups }\end{array}$ & $\begin{array}{l}\text { Data was collected by } \\
\text { different institutions thus } \\
\text { the chances for error was } \\
\text { high }\end{array}$ & $\begin{array}{l}\text { There is an increase in the } \\
\text { number of randomized } \\
\text { trials performed over } \\
\text { the years on e-health } \\
\text { evaluation in Africa. }\end{array}$ \\
\hline 10 & Bali S (2018) & $\begin{array}{c}\text { Barriers to } \\
\text { development of } \\
\text { Telemedicine in } \\
\text { Developing countries }\end{array}$ & $\begin{array}{l}\text { Qualitative } \\
\text { Study }\end{array}$ & Articles Reports & Literature Review & $\begin{array}{c}\text { Policy barriers lack of } \\
\text { Telemedicine organizational } \\
\text { structures and lack of } \\
\text { physicians are all limitations }\end{array}$ & $\begin{array}{l}\text { Telemedicine has not yet } \\
\text { become an integral part } \\
\text { of the healthcare system } \\
\text { in Africa but growing } \\
\text { gradually }\end{array}$ \\
\hline 11 & $\begin{array}{l}\text { Ruxwana NL } \\
\text { et al. (2010) }\end{array}$ & $\begin{array}{l}\text { Reviewed articles } \\
\text { ICT applications as } \\
\text { e-health solutions in } \\
\text { rural healthcare in the } \\
\text { Eastern Cape Province } \\
\text { of South Africa The } \\
\text { potential of ICT for } \\
\text { rural communities }\end{array}$ & $\begin{array}{l}\text { Mixed } \\
\text { Methods }\end{array}$ & $\begin{array}{l}38 \text { completed } \\
\text { questionnaires }\end{array}$ & $\begin{array}{l}\text { Questionnaires } \\
\text { interviews case } \\
\text { study }\end{array}$ & $\begin{array}{c}\text { Shortage of ICT } \\
\text { infrastructure hardware and } \\
\text { software }\end{array}$ & $\begin{array}{l}\text { Most participating staff } \\
\text { saw their low level of ICT } \\
\text { skills as a major hindrance } \\
\text { to the growth of e-health } \\
\text { solutions and they also } \\
\text { believed that lack of } \\
\text { information is a major } \\
\text { hindrance to e-health } \\
\text { application }\end{array}$ \\
\hline 12 & $\begin{array}{l}\text { Shiferaw F } \\
\text { \& Zolfo M } \\
\text { (2012) }\end{array}$ & $\begin{array}{l}\text { The role of information } \\
\text { communication } \\
\text { technology (ICT) } \\
\text { towards universal } \\
\text { health coverage: } \\
\text { the first steps of a } \\
\text { telemedicine project in } \\
\text { Ethiopia }\end{array}$ & $\begin{array}{l}\text { Mixed } \\
\text { Method }\end{array}$ & $\begin{array}{l}10 \text { healthcare } \\
\text { sites for case } \\
\text { study with two } \\
\text { physicians per } \\
\text { site }\end{array}$ & $\begin{array}{l}\text { Descriptive case } \\
\text { study interview }\end{array}$ & $\begin{array}{l}\text { During the implementation } \\
\text { of the project about } 70 \% \\
\text { of the population faced } \\
\text { connectivity issues among } \\
\text { others which led to the } \\
\text { failure of the pilot }\end{array}$ & $\begin{array}{c}61 \% \text { of physicians and } \\
83 \% \text { of nurses knew about } \\
\text { Telemedicine and how to } \\
\text { use the system }\end{array}$ \\
\hline 13 & $\begin{array}{l}\text { Scott RE } \\
\text { \& Mars M } \\
(2015)\end{array}$ & $\begin{array}{l}\text { Telehealth in the } \\
\text { developing world: } \\
\text { current status and } \\
\text { future prospects }\end{array}$ & $\begin{array}{l}\text { Qualitative } \\
\text { Study }\end{array}$ & $\begin{array}{l}\text { PubMed articles } \\
\text { e-health books } \\
\text { and reports }\end{array}$ & Literature Review & $\begin{array}{c}\text { Poverty lack of Telemedicine } \\
\text { equipment shortage of } \\
\text { health workers }\end{array}$ & $\begin{array}{l}\text { Africa is plagued by } \\
\text { shortage of healthcare } \\
\text { personnel in rural areas } \\
\text { poor transportation } \\
\text { network and the main way } \\
\text { to resolve Telemedicine } \\
\text { issues is to establish an } \\
\text { evidence based Telehealth } \\
\text { strategy }\end{array}$ \\
\hline 14 & $\begin{array}{l}\text { Kahn JG et al. } \\
\quad(2010)\end{array}$ & $\begin{array}{l}\text { Mobile' Health Needs } \\
\text { and Opportunities in } \\
\text { Developing Countries }\end{array}$ & $\begin{array}{l}\text { Qualitative } \\
\text { Study }\end{array}$ & $\begin{array}{l}\text { Exhibits and } \\
\text { case studies }\end{array}$ & $\begin{array}{c}\text { Review case study } \\
\text { exhibits }\end{array}$ & $\begin{array}{l}\text { Lack of local mhealth } \\
\text { technical capacity training }\end{array}$ & $\begin{array}{l}\text { There is a huge potential } \\
\text { for m-health including } \\
\text { economic outcomes }\end{array}$ \\
\hline 15 & $\begin{array}{l}\text { Combi C et al. } \\
\qquad(2016)\end{array}$ & $\begin{array}{c}\text { Telemedicine for } \\
\text { Developing Countries }\end{array}$ & $\begin{array}{l}\text { Qualitative } \\
\text { Analysis }\end{array}$ & Journals reports & Literature Review & $\begin{array}{c}\text { Training and financial } \\
\text { aspects when designing } \\
\text { Telemedicine software } \\
\text { systems for developing } \\
\text { countries }\end{array}$ & $\begin{array}{l}\text { A taxonomy of features of } \\
\text { Telemedicine were derived } \\
\text { from the projects and } \\
\text { systems available }\end{array}$ \\
\hline 16 & $\begin{array}{l}\text { Déglise C et } \\
\text { al. (2012) }\end{array}$ & $\begin{array}{l}\text { SMS for disease } \\
\text { control in developing } \\
\text { countries: a systematic } \\
\text { review of mobile } \\
\text { health applications }\end{array}$ & $\begin{array}{l}\text { Qualitative } \\
\text { Study }\end{array}$ & $\begin{array}{l}98 \text { applications } \\
\text { evaluated }\end{array}$ & $\begin{array}{c}\text { Peer and } \\
\text { literature review }\end{array}$ & $\begin{array}{l}\text { Connectivity and lack of } \\
\text { information }\end{array}$ & $\begin{array}{l}\text { Majority of the } \\
\text { applications focused } \\
\text { on HIV/AIDS using } \\
\text { bulk messaging by the } \\
\text { population. Mobile phones } \\
\text { are promising for disease } \\
\text { control interventions in } \\
\text { developing countries }\end{array}$ \\
\hline
\end{tabular}




\begin{tabular}{|c|c|c|c|c|c|c|c|}
\hline 17 & $\begin{array}{l}\text { Jennings L \& } \\
\text { Gagliardi L } \\
\text { (2013) }\end{array}$ & $\begin{array}{c}\text { Influence of mhealth } \\
\text { interventions on } \\
\text { gender relations in } \\
\text { developing countries: } \\
\text { a systematic literature } \\
\text { review }\end{array}$ & Qualitative & $\begin{array}{c}173 \text { articles } \\
\text { were retrieved } \\
\text { for review }\end{array}$ & $\begin{array}{c}\text { Systematic } \\
\text { Literature Review }\end{array}$ & $\begin{array}{l}\text { Lack of programs that } \\
\text { will transfer rather than } \\
\text { reinforce the digital divide }\end{array}$ & $\begin{array}{l}\text { Mobile phone programs } \\
\text { can influence gender } \\
\text { relations in positive ways }\end{array}$ \\
\hline 18 & $\begin{array}{l}\text { Chanda KL } \\
\text { \& Shaw JG } \\
\text { (2010) }\end{array}$ & $\begin{array}{l}\text { The development of } \\
\text { telehealth as a strategy } \\
\text { to improve health care } \\
\text { services in Zambia }\end{array}$ & $\begin{array}{l}\text { Descriptive } \\
\text { Study }\end{array}$ & $\begin{array}{l}\text { reviews } \\
\text { personal } \\
\text { experience } \\
\text { news report }\end{array}$ & Literature Review & $\begin{array}{c}\text { Lack of modern } \\
\text { communication technologies } \\
\text { underdevelopment financial } \\
\text { aspects }\end{array}$ & $\begin{array}{c}\text { Reduces barrier between } \\
\text { patients and physicians in } \\
\text { rural areas }\end{array}$ \\
\hline 19 & $\begin{array}{l}\text { Bagayoko CO } \\
\text { et al (2014) }\end{array}$ & $\begin{array}{l}\text { Medical and economic } \\
\text { benefits of telehealth } \\
\text { in low- and middle- } \\
\text { income countries: } \\
\text { results of a study in } \\
\text { four district hospitals } \\
\text { in Mali }\end{array}$ & $\begin{array}{l}\text { Mixed } \\
\text { Methods }\end{array}$ & $\begin{array}{l}\text { Questionnaire } \\
\text { administered } \\
\text { to healthcare } \\
\text { officials in } \\
\text { four district } \\
\text { hospitals }\end{array}$ & $\begin{array}{c}\text { Survey } \\
\text { consultation logs }\end{array}$ & $\begin{array}{l}\text { Enhanced ultrasound } \\
\text { training }\end{array}$ & $\begin{array}{l}\text { Telehealth activities } \\
\text { contributed in improving } \\
\text { medical diagnostics in } \\
\text { obstetrics and cardiology } \\
\text { increase in attendance } \\
\text { records at health centers }\end{array}$ \\
\hline 20 & $\begin{array}{l}\text { Bagayokoa } \\
\text { CO et al. } \\
(2011)\end{array}$ & $\begin{array}{l}\text { Can ICTs contribute to } \\
\text { efficiency and provide } \\
\text { equitable access to the } \\
\text { health care system in } \\
\text { sub-Saharan Africa? } \\
\text { The Mali experience }\end{array}$ & $\begin{array}{l}\text { Qualitative } \\
\text { Study }\end{array}$ & $\begin{array}{l}\text { RAFT reviews } \\
\text { reports and } \\
\text { Telemedicine } \\
\text { reviews in Mali }\end{array}$ & $\begin{array}{l}\text { There are no } \\
\text { reports on } \\
\text { unsuccessful } \\
\text { projects }\end{array}$ & $\begin{array}{l}\text { There are no reports on } \\
\text { unsuccessful projects }\end{array}$ & $\begin{array}{l}\text { Numerous Telemedicine } \\
\text { projects were reviewed } \\
\text { including RAFT Pact-e- } \\
\text { sante including medical } \\
\text { education and the support } \\
\text { of health professionals } \\
\text { with the use of innovative } \\
\text { tools }\end{array}$ \\
\hline
\end{tabular}

According to Table 1, Telemedicine is important in helping health practitioners diagnose and treat patients with the use of Information Communication Technology. The authors opined that the majority of the population in Ghana, Ethiopia and Africa as a whole living in remote areas and slums with little or no access to healthcare as well as limited benefits of being insured or no health insurance at all [2-6]. Mobile Health and other ICTs in this case is the better way to reach out to patients in remote areas with chronic diseases and lack of medical personnel to attend to them due to poverty which prevents them from moving to larger cities for treatment. This is evident from the results of case and pilot studies carried out in this communities to assess the impact of mobile Health and other ICTs which yielded positive results to a greater extent [6-12].

\section{Research Design}

The purpose of this study was to use a qualitative method to determine the current state and investigate quality in Healthcare and telemedicine interventions in Cameroon. One overarching research questions guided this research: "What is the current state of healthcare in Cameroon".

\section{Participant}

The study participants that volunteered to participate in the interview were medical practitioners in Cameroon's public hospitals. Participants in the study are very familiar with the use of health information technology tools. Participants signed an informed consent form.

\section{Data Collection}

The study adopted a qualitative data collection method. The interview method was chosen to obtain in-depth information in regard to telemedicine interventions

\section{Data Analysis}

Indicators from the interview protocol were identified to assist with the coding. Researchers coded the interview transcript. Themes and patterns were then compiled according to the research questions. Results from the analysis are discussed in the following sections.

\section{Qualitative Results}

Results indicate several trends in telemedicine and Health Information Technology as well as various challenges that confront them in Cameroon.

\section{What Do You Think About the State if Healthcare in Cameroon?}

Interviewee A felt that It is a mess. "Despite the number of doctors being trained in Cameroon each year, we still face a very high patient to doctor ratio (we have a lot of brain drain). It is even worse at the peripheries and villages. Few doctors agree to practice there, and so there is very minimal access to specialized health care. As a result of it, multiple clandestine "clinics" are opened up and manned by unqualified nurses". Interviewee B felt that A lot is wrong with the health system, not even sure where to start: Limited resources is a real problem coupled with lack of Universal Health coverage or some sort of pension scheme makes things worse. This is even more apparent when you leave the big towns "I think there is no accountability in most of our public health facilities and that's why money and the little resources are misused"; Corruption - but that's everywhere in the country so not surprising. The fact that when MDs graduate from public schools, they only receive salaries 2-3 years later (1 year later if you have the right contacts or if you're lucky) is a factor that plays into malpractices in my opinion. Also, most doctors won't want to work in remote areas where they are 
sent because of the lack of resources that they have at their disposal in those facilities. "We can agree that everyone is more efficient when they have proper working conditions" [12-14]. Interview C felt disappointed "The state of health in Cameroon is still in a deplorable state. Central hospitals are grossly under equipped with majority of staff unsatisfied and unmotivated. This has bred lack of empathy towards patients .Despite an increase in number of medical doctors being posted by state ,most of them remain redundant as most of the facilities lack the basic infrastructure to enable them work. The current crises in North and South West of Cameroon has only made matters worse". Do you understand the concept of Telemedicine? If Yes respond to the next question? All interviewees understood the concept of telemedicine. Do You Think Telemedicine Can Solve the Current Healthcare Challenges in Cameroon?

Interviewee A felt "While telemedicine can never replace one on one patient contact, it will go a long way in solving some of the health problems in Cameroon [14-19]. Take the aforementioned challenges in answer 1, telemedicine can ensure patient's access to doctors, thus reducing the cost of transportation to the cities, as well as reducing polypharmacy (which is common practice when solely nurses prescribe). With the current crises in both Anglophone regions, it is even more necessary." Interviewee B felt "I don't think Telemedicine alone cannot solve healthcare challenges in Cameroon. She stated, I think that for Telemedicine to be effective, the underlying healthcare system needs to be strong. We need proper policies which are actually implemented in place etc. Telemedicine will obviously solve some problems such as cut waiting times for patients and all .But work needs to be done to:sensitize the public on this method of health care delivery. You know how skeptical people can get, and some people prefer face to face exchanges with their doctors-Confidentiality of the patient information needs to be assured-Also the Internet coverage in the country is not the most optimal and there are still people who don't use smart phone, so Telemedicine might mostly be beneficial for people in urban areas (but are they the most in need?)-Healthcare professionals need to be trained in informatics which is obviously not the case at the moment in Cameroon accountable". Interviewee " $\mathrm{C}$ " feels Cameroon is not ripe enough to adopt telemedicine "To begin with Cameroonians are still struggling to make ends meet with a majority still leaving in poverty, access to health care is still an issue and the state have not achieved the basic infrastructure in most of her health institutions talk less of introducing this technology which will be unarguably capital intensive.

As a nation in the $21^{\text {st }}$ century we are still battling with power outages, horrible and unreliable internet connectivity, disgracefully bad roads, food insecurity, scarcity of portable water, shamefully bad governance and corruption in high places; Introduction of such a technology will be a misplaced priority, Rather, hospitals should be equipped, roads paved, bridges constructed, ambulance service revamped; effective presence of nurses, physicians and surgeons should be enforced and all ghost workers taken out of pay roll, charged and fine with abandonment of public office. Corruption that sabotages public services and devastates vital infrastructure should be rooted out and penalized There are already ongoing national malaria, HIV, TB, neonatal, infant and maternal mortality control programs, their success so far just need to be evaluated and scaled up. Telemedicine will not be able to save the millions who die every year from diarrheal diseases. It will not curb spread of tuberculosis or AIDS nor will it end the many women who die of pregnancy related complications. We all know the solutions to this problem so let's *fix the Cameroon health system*. On other hand we can consider doing a pilot study to assess its acceptance, uses, and challenges in our own context".

\section{Discussion and Conclusion}

The current study offers several implications for practice and research. First, there is a need for improving government policies and healthcare policies. The design should focus not only on the technological aspects, but also on uniformity on the goal, objectives and expectations for patients. Telemedicine is the use of medical information from one site to another, through electronic communications devices for improving a patient's health status. Telemedicine involves a various applications and services using a two-way video, email, wireless tools and other forms of telecommunication technologies. The market for telemedicine is growing rapidly across the world. One of the important qualities of telemedicine is that it puts a patient exactly into the focal point of care. There are drawbacks, of course, such as electronic glitches, physician resistance, and inadequate assessment, but there are also advantages. Those advantages include convenience, costefficiency, time saved from waiting room, expedited transmission of MRIs or X-rays, and privacy assurance. In addition, telemedicine requires communication and information infrastructure. The technical infrastructure elements differentiate depending on the telehealth services and organization plans to offer. In an environment with a shortage on healthcare staff, greater incidence of chronic, telemedicine offers a tool to improve the efficiency in the delivery of healthcare. Finally, despite the fact that telemedicine is a key component in achieving basic universal health care as suggested by the World Health Organization and United Nations Sustainable Development Goals, the result of our reviews prove that the immediate solution to the deplorable state of healthcare in Cameroon is for government to implement sound health policies rather than go the way of Telemedicine because an average Cameroonian will not be able to afford the cost of health associated with telemedicine infrastructure.

\section{References}

1. Blaya JA, Fraser HS, Holt B (2010) E-health technologies show promise in developing countries. Health Affairs 29(2): 244-251.

2. Bali, Surya (2018) Barriers to Development of Telemedicine in Developing Countries. Telemedicine. Intech Open.

3. Bagayoko, Cheick Oumar, Pecoul D, Niang M, Bediang G, et al. (2014) Medical and economic benefits of telehealth in low-and middle-income countries: results of a study in four district hospitals in Mali. BMC health services research 14(1): S9. 
4. Bagayokoa CO (2011) Can ICTs contribute to the efficiency and provide equitable access to the health care system in Sub-Saharan Africa? The Mali experiences. Yearbook of medical informatics 20(1): 33-38.

5. Bediang, Georges (2014) The RAFT telemedicine network: lessons learnt and perspectives from a decade of educational and clinical services in low-and middle-incomes countries. Frontiers in public health 2: 180.

6. Chanda, Kenneth L, Jean G Shaw (2010) The development of telehealth as a strategy to improve health care services in Zambia. Health Information \& Libraries Journal 27(2): 133-139.

7. Combi, Carlo, Gabriele Pozzani, Giuseppe Pozzi (2016) Telemedicine for developing countries. Applied clinical informatics 7(4): 1025-1050.

8. Déglise, Carole, L Suzanne Suggs, Peter Odermatt (2012) SMS for disease control in developing countries: a systematic review of mobile health applications 18(5): 273-281.

9. Edoh, Thierry OC (2016) Predicting telemedicine system user satisfaction in sub-Saharan Africa. ICT Express 2(4): 163-167.

10. Ekanoye, Femi (2017) Telemedicine diffusion in a developing country: A case of Nigeria. Science Journal of Public Health 5(4): 341

11. Jennings, Larissa, Laina Gagliardi (2013) Influence of mHealth interventions on gender relations in developing countries: a systematic literature review. International journal for equity in health 12(1): 85.

12. Jivraj, Imran (2011) Prevalence and severity of diabetic retinopathy in Northwest Cameroon as identified by teleophthalmology. Telemedicine and e-Health 17(4): 294-298.

\section{ISSN: 2574-1241}

DOI: 10.26717/BJSTR.2019.22.003725

Foluso Ayeni. Biomed J Sci \& Tech Res

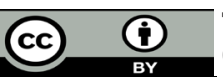

This work is licensed under Creative Commons Attribution 4.0 License

Submission Link: https://biomedres.us/submit-manuscript.php
13. Kahn, James G, Joshua S Yang, James S Kahn (2010) Mobile health needs and opportunities in developing countries. Health Affairs 29(2): 252258.

14. Mars, Maurice (2013) Telemedicine and advances in urban and rural healthcare delivery in Africa. Progress in cardiovascular diseases 56(3): 326-335.

15. Mars M (2010) Health capacity development through telemedicine in Africa. Yearbook of medical informatics 19(1): 87-93.

16. Ruxwana NL, Herselman ME, Conradie DP (2010) ICT applications as e-health solutions in rural healthcare in the Eastern Cape Province of South Africa. Health information management journal 39(1): 17-29.

17. Sarfo, Fred S (2017) Tele-neurology in sub-Saharan Africa: a systematic review of the literature. Journal of the neurological sciences 380: 196199.

18. Scott, Richard E, Maurice Mars (2015) Telehealth in the developing world: current status and future prospects. Smart Homecare Technology and TeleHealth 3: 25-37.

19. Shiferaw, Fassil, Maria Zolfo (2012) The role of information communication technology (ICT) towards universal health coverage: the first steps of a telemedicine project in Ethiopia. Global health action 5(1): 1-8.

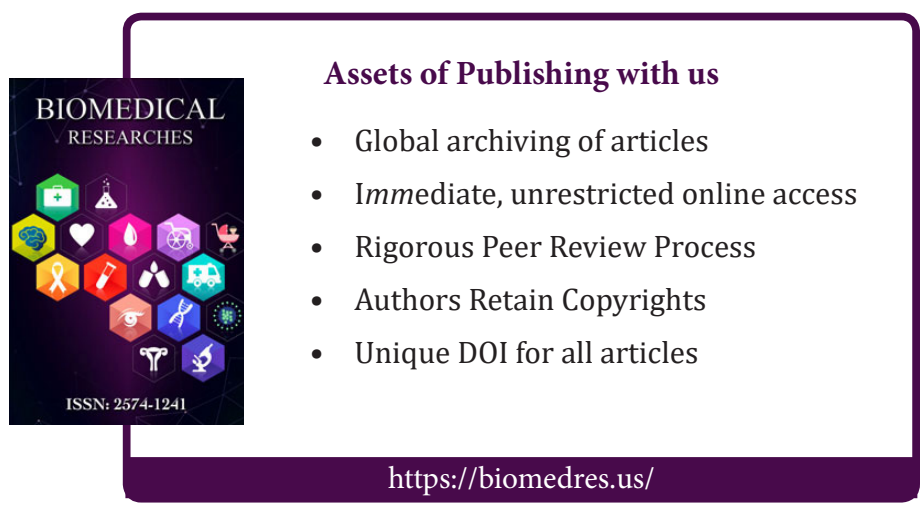

